\title{
Organizational Structure of Institutional Investment in Bandung City, West Java Province, Indonesia
}

\author{
Dewi Gartika
}

Researchers at Board of Research, Development and Application of Science and Technology of West Java Province

\begin{abstract}
In Act No. 32 of 2004, which is now revised to Act No. 23 of 2014 on Regional Government, one of the obligatory functions that must be implemented by local governments is the business of investment, it is reinforced in Government Regulation No. 38 Year 2007 on the dealings between the central government, provincial government and district / city governments, who explained that one of the local government authority is in the field of investment. As an obligatory, then the investment affairs should be managed optimally under a regional work units (SKPD) which has full authority from the planning, implementation, monitoring and control. This is because the performance of investments interlinked with investment licensing, employment, socio-economic impacts, environmental impacts and others. In the city government Bandung, capital investment affairs conducted by the Investment Sector at Bappeda Bandung, equivalent to Echelon 3. This paper review about the low performance of the investment in the Government of Bandung, which is caused by the relatively small given the authority and lack of human resources managers of investment, This paper consists of three parts: the first part Introduction, discussed the organizational structure, the second part of the discussion, discuss the organizational structure of institutional investment in the city of Bandung, and the third part of the conclusion.
\end{abstract}

Keywords: Structure, Organizational, Investment.

\section{Introduction}

The structure holds a very important role in the running of the organization. The structure enables an organization to achieve its objectives. Whatever the organization, the organization is always established to achieve the goal. There orientation to be achieved by the establishment of an organization and orientation will be more easily achieved if there is a division of labor that is implemented in a structure. The organization is a deliberate arrangement of a number of people to achieve certain goals (Robbins and Coulter, 2004.. 16). These goals can be a benefit (companies), public policy (government) and social change (a nonprofit organization). To achieve these objectives the necessary division of labor and the appropriate placement for everyone, it takes a structure as the embodiment of organizational strategy into implementation on the ground. That is none other than that organizational goals can be achieved effectively and efficiently is to create a design structure that has the flexibility to adjust the dynamic conditions in which all things can change quickly. To that required a formal structure that can support and facilitate members of the organization in the implementation of the organization's work. These activities may be regarded as an organization that is defined as the process of creating an organizational structure (Robbins and Coulter, 2004, p 254).

Leach, Stewart, and Wish in The Changing Organization and Management of Local Government (1994: 52), explains that the structure of an organization is the pattern of rules, positions, and roles that give shape and coherence to its strategy and process, and is typically Described in organization charts, job descriptions and patterns of authority.

As has already been studied by the researchers, the first pattern in the change process that occurs mainly public organizations in many countries in Europe and North
America. Chrisholm M. (2000a, 2000b) has conducted a study on the restructuring of local government organization in the UK which shows the tendency that. In the United States, the bureaucratic reform stems from David Osborne and Ted Gaebler (1992) which inject the ideas of authority should be decentralized levels of the organization from the top level of government to the lower levels of government organizational levels. Oakerson R. (2006) has conducted a study on the restructuring of local government organization in the United States where he saw a boost to the local governments to intensively make changes bureaucracy.

In terms of organizational studies, according to Mintzberg (1979), top-down procedures in the establishment of organizational units (unit grouping) if the stems of the common needs (mission or organizational objectives to be achieved) to specific occupations. Further according to Mintzberg (1979: 288-291), the greater the control force from outside the organization, the more formalized organizational structure and more centralized or concentrated decision-making power of organization. Such conditions will eventually form a bureaucratic entity, which is an organization in which power is concentrated on the leader, the procedure handcuff employees - so they can not develop their creativity, work processes standardized rigid - so that workers will not be able to innovate, communication is formal, and reporting strictly regulated. Such organizations have the adaptability to environmental changes is low.

Hall (1977) states that the organizational structure affects two things, namely individual behavior and organizational performance (efficiency, morale, and effectiveness). In the UK, Chrisholm M. (2000a, 2000b) view that the restructuring of local government in England is also directed to the "privatization". According Valler, Wood, and North (2000), since the 1980s in the UK local government restructuring analytically must be associated with the representation of business interests at the local level. In Canada, Brunet-Jailly 


\section{International Journal of Science and Research (IJSR) \\ ISSN (Online): 2319-7064}

Index Copernicus Value (2013): 6.14 | Impact Factor (2014): 5.611

(2003) found that the inter-municipalities cooperation brings enormous economic benefits for local governments. Brunet Jailly so also see that the model of privatization of local government within the framework of the restructuring is very helpful. In Australia, B. \& L. Crase Dollery (2004, 2005) critically examined the restructuring of local government organizations that have so far been oriented towards the integration of the free market in order to achieve efficiency in the public service. However, in the end Dollery and Crase continue to recognize the importance of orienting the local government organization on the ways the private sector in the process of restructuring the local government organization. In New Zealand, a study on the restructuring of local government organizations have also been carried out (McKinlay Douglas Limited, 2006). In this case, they are reviewing the organizational restructuring of local government in New Zealand, which then suggests the importance of privatization and efficiency. Meanwhile in developing countries, empirical studies on the restructuring of local government organizations have also been carried out. In this regard, reform of local government organizations directed to the role of private organizations and nongovernmental institutions to take over the functions of government as much as possible (Dwarika Nath Dhungel, 1996).

In Indonesia, the bureaucratic reform was carried out as a continuous effort to create an organization that is effective and efficient bureaucracy towards good governance that is coveted by all parties over the years. The government made improvements in bureaucratic body in several ways. One of them issued Government Regulation No. 41 of 2007 concerning the regional Organization. Government Regulation No. 41 of 2007 is the platform for Local Government in preparing the Organization Chart, a local device in accordance with regional characteristics, potential and needs of each region.

\section{Discussion}

Investment Affairs besides set as obligatory, also specifically regulated in the Law of the Republic of Indonesia Number 25 Year 2007 on Investment. This law mandates that the investment should be part of the implementation of the national economy and placed in an effort to: (1) increase the growth of the national economy; (2) create jobs; (3) enhancing the capacity and capability of national technology; and (4) encouraging the development of community economy and public welfare in a competitive economy. To that end, local and central government have a shared responsibility in providing stimulus to the development of the real sector of the economy through investment. Furthermore, in the explanation of Law No. 25 of 2007 on Investment, explained that :

"This law ordered that the government improve coordination among government agencies, inter-governmental institution with Bank Indonesia, and between government agencies and the Regional Government. Coordination with Local Government should be in line with the spirit of regional autonomy. Local Government together with the agencies or institutions, both private and government, must be improved further, both in the development of potential opportunities in the area as well as the promotion and coordination of investment services. Local Government run broad autonomy to organize and manage the affairs of investment activity based on the principle of regional autonomy and duty of assistance or deconcentration. Therefore, improvement of institutional coordination should be measured on the speed of granting licenses and investment facilities at competitive costs. To comply with the principles of economic democracy, this Act also ordered the drafting of laws and regulations regarding business fields closed and open with conditions, including the business sector should be partnership or reserved for micro, small, medium and cooperative. "

With the enactment of Law No. 32 of 2004 on Regional Government and Law No. 33 of 2004 on Financial Balance between Central and Local Government, the District / City Government authorized by the Central Government to undertake the development of the resource based on the authority granted in a system of apportionment that is fair, proportionate, democratic, transparent, and efficient in order to finance the implementation of decentralization, taking into account the potential, conditions and needs of the region, as well as the amount of funding the implementation of deconcentration and assistance.

In Law No. 32 In 2004, capital investment is obligatory, it is reinforced in PP 38 of 2007 where one of the local authorities is an investment. Law Number 32 Year 2004 regarding Regional Government as amended for the last time by Act No. 12 of 2008, explained that each province has the right and duty to regulate and manage their own affairs and seeks to improve the efficiency and effectiveness of the organization administration and service to the community.

Under the provisions of Article 14 paragraph (1) of Law No. 32 of 2004 explained that the affairs under the authority of local government to the district / city is a large-scale affair district / city consists of obligatory functions and affairs of choice. Obligatory for districts / cities include education, health, population, and others including the capital investment area.

Government affairs in the field of investment is government affairs shall be convened provincial government and administration of the district / city, which is the legal basis referred to in Article 7 paragraph (2) of Government Regulation No. 38 of 2007 on the Division of Government Affairs between the Government, Provincial Government and Regional Government of Regency / City.

The existence of regional autonomy has liberated areas to develop according to their potential and develop its investment either individually or through cooperation with the private sector, both private foreign and domestic private and without forgetting the roots of the potential of the region itself, so that the development of the area can running optimally.

As stipulated by the Law of the Republic of Indonesia Number 25 Year 2007 regarding Investment, the investment 


\section{International Journal of Science and Research (IJSR) \\ ISSN (Online): 2319-7064}

Index Copernicus Value (2013): 6.14 | Impact Factor (2014): 5.611

must be aimed at the improvement of national economic growth, create jobs, improve the capacity and capability of national technology; and encourage the development of community economy and public welfare in a competitive economy. Thus, the investment must be managed optimally and completely covering the aspects of planning, implementation, monitoring and control. This is because the performance of investments interlinked with investment licensing, employment, socio-economic impacts, environmental impacts and others.

Investment Affairs in the Government of Bandung entered in the organizational structure Bappeda Bandung namely investment field or equivalent echelon 3. intact, Bappeda
Bandung organizational structure consists of the Head of the Agency, which oversees the secretariat led by the secretary of the Agency, the secretariat is in charge 3 sub-sections, namely general and employment sub-section, sub-section of finance, and sub part of the program, each sub-section headed by the Head of section. Head of the agency also oversees six fields, namely 1) Field of Spatial Planning, Infrastructures, 2) Field of Economic Planning and Finance, 3) Planning Government, 4) of Social Planning of Cultural and Welfare Society, 5) Research, Development, and Statistics, and 6) the Investment Sector, each of which is led by the Head of Division, and oversees each Sector Sub Sector 2, each of which is led by the Head of Sub Division.

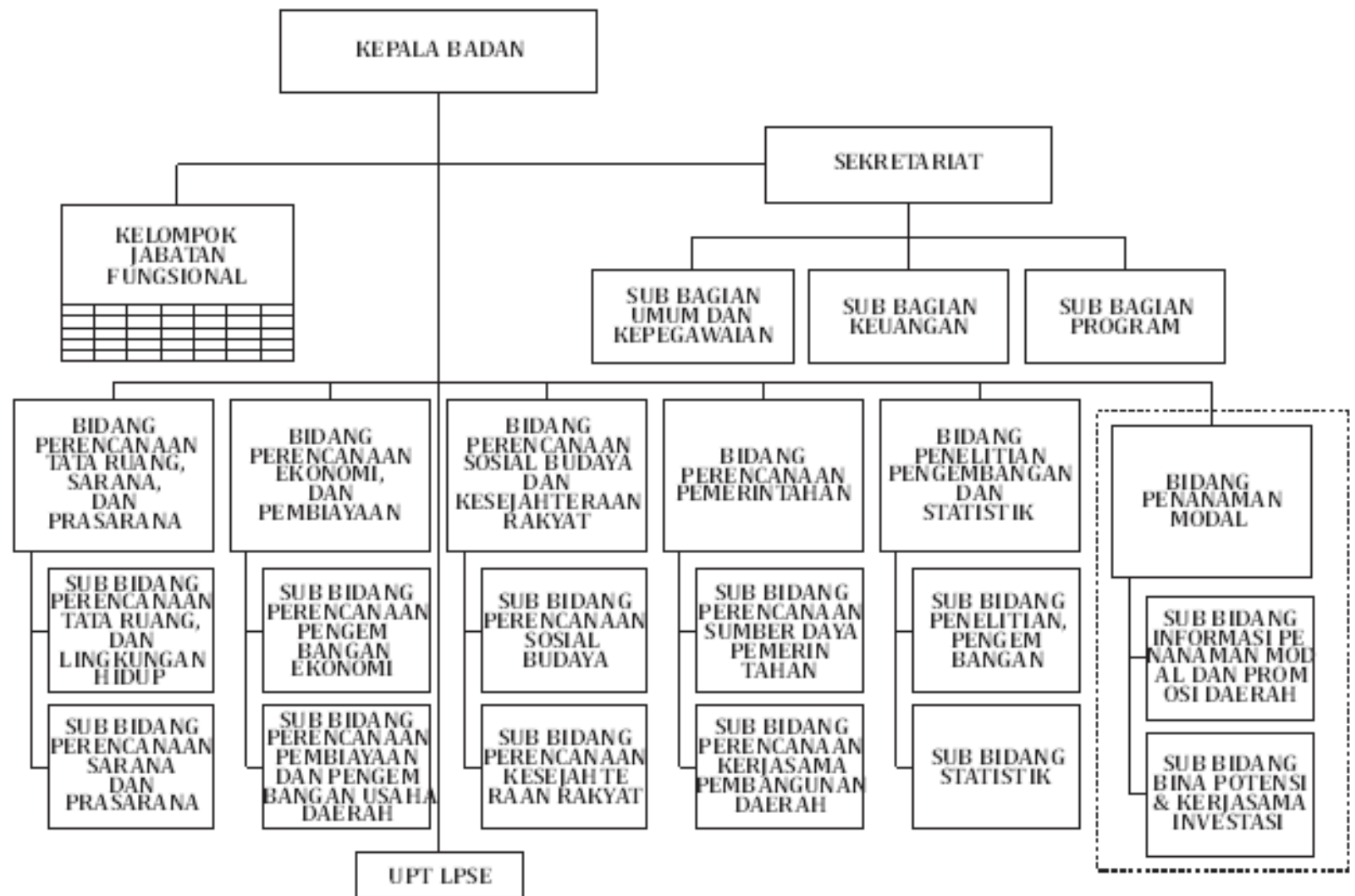

Figure 1: The institutional structure of investment in Bandung Source: Analysis of author of Organizational Structure BAPPEDA, 2016.

When viewed under Government Regulation No. 41 of 2007 concerning the regional Organization, the Bappeda Bandung has the most number of fields between Bappeda City / Regency in West Java and consists of 6 fields. Government Regulation No. 41 Year 2007 Article 26, paragraph 2, states that the organizational structure of the Agency in the form most widely consists of four fields and oversees the Division 2, this condition is certainly at odds with Government Regulation No. 41 of 2007. The organizational structure of the fat will certainly affect performance therefore can not run optimally because the workload is too great. In this condition, Bappeda should be able to carry out three obligatory well as the matters of planning, statistics and business affairs of the investment, plus one more business research and development that is a matter that is inherent in all the obligatory functions and affairs of choice.
In the structure of city government Bandung, especially at institutions Bappeda, the Investment Sector placed in a central position in growing investment in Bandung. However, low echelon owned (equivalent echelon 3 ) become functional barriers to the performance of investments in the city of Bandung. Investment Sector, chaired by the Head of the charge of 2 Sub-Sector, namely Sub-Sector Investment Information and Promotion of Regional and Sub-Sector Potential Cooperation and Investment, this has resulted in suboptimal functions of coordination, supervision functions and control functions in the field of investment.

In general, the Core Business Bappeda is planning so Bappeda not have the authority to exercise control and supervision over the performance of investments in the city of Bandung, especially related to foreign companies in the city of Bandung. Control and Supervision of the foreign 


\section{International Journal of Science and Research (IJSR) \\ ISSN (Online): 2319-7064}

Index Copernicus Value (2013): 6.14 | Impact Factor (2014): 5.611

investment and domestic investment to be blocked, the supervision of the use of the number of foreign workers in the company can not be done optimally, oversight of the development of the invested amount and type of managed investment whether in accordance with the operating licenses in early too can not be done optimally, including the obligation for each investor to submit a report on investment activity according to the Law No. 25 of 2007 yet also can be performed optimally. Investment Activity Report (LKPM) is the regular reports on the progress of the company and the obstacles faced by the investors. LKPM intended to monitor the realization of investment and production. LKPM include the investment activities of the company in any location and line of business investment, unless the trading business. For companies that conduct investment activities in the field of trade, LKPM fairly based on the location set forth in Principle License.

Investment Sector Bandung also do not have a marketing strategy the city to create an attraction for investment and competitiveness of the city as a place for investment as compared to other cities or regions. Yet its marketing strategy for the city of Bandung seen from the absence of market strategy and marketing program of the city. The absence of investment markets strategy Bandung reflected: the unclear investment targets (businesses) are unreliable, not specifically the formulation of differentiation Bandung, Bandung is no clear positioning in terms of capital investment.

Bandung city government's efforts in fostering capital investment will not be separated from the involvement of stakeholders who will establish a friendly environment for investment. For that communication with stakeholders is the key to success, Bandung City Government should continue to establish communication with stakeholders such as the business community, the creative community of the city, and college. Lack of communication can to strategic investments, as a result of Bandung City Government lacks the idea of creating breakthroughs in developing the potential of city resources or just improve the city's infrastructure.

Assertiveness scope of the Investment Sector at Bappeda Bandung also become a problem, in practice a lot of capital investment, many investors who make capital investment process through this field. The process of investment in the city of Bandung can be done through the 'doors' to another, for example through the institution or a higher office in the government structure Bandung. The occurrence of indecision or ambiguity scope of work in the investment field is also a problem that will inhibit the function of this field optimally.

The role of positions (job role) is the number of tasks or roles that must be carried out or are expected to do in an office or a structure within the organization. An office is said to have functional barriers if these positions are not or are less able to demonstrate its role. Existence and clarity Main Duties and Functions (Auth) held a position of absolute thing, another thing is the ability of the incumbent to run his Auth. Therefore, for institutional investment in the city of Bandung this to be effective, it is essential to the Investment Sector is no longer a part in the organizational structure of Regional
Development Planning Agency in Bandung, but formed into Work Units (SKPD) has shaped the Department of Investment, this is due to Investment in Development Planning Agency Organizational Structure of Bandung great authority, great work volume, but does not offset the amount of human resources, in addition to Capital Investment is obligatory according to the Local Government Regulation No. 38 of 2007 on the Division of Government Affairs between the Government, Provincial Government and Regional Government of Regency / City and Law No. 23 of 2014 on local government, where the affairs of compulsory and contained in the form of the Department.

\section{Conclusion}

The structure holds a very important role in the running of the organization. The structure enables an organization to achieve its objectives. Whatever the organization, the organization is always established to achieve the goal. There orientation to be achieved by the establishment of an organization and orientation will be more easily achieved if there is a division of labor that is implemented in a structure. The role of positions (job role) is the number of tasks or roles that must be carried out or are expected to do in an office or a structure within the organization. An office is said to have functional barriers if these positions are not or are less able to demonstrate its role. Existence and clarity Main Duties and Functions (Auth) held a position of absolute thing, another thing is the ability of the incumbent to run his Auth. Therefore, for institutional investment in the city of Bandung this to be effective, it is essential to the Investment Sector is no longer a part in the organizational structure of Regional Development Planning Agency in Bandung, but formed into Work Units (SKPD) has shaped the Department of Investment so that it can organize the obligatory intact including planning, implementation, monitoring and control of capital investment in the city of Bandung.

\section{References}

[1] Aris Munanto. 2012. Influence of Organizational Structure Effectiveness Against Land Office in the province of Bengkulu. Thesis Public Administration Padjadjaran Bandung.

[2] Anwar, Syaifuddin. (2007). Validity and Reliability, Yogyakarta: Student Library

[3] Bagozzi, R.P., H. Baumgartner and Y. Yi. (1992). State versus Action Orientation and the Theory of Reasoned Action: An Application to the Coupon Usage, Journal of Consumer Research, 18, 505-518

[4] Bennis, Warren \& Mische, Michael. 1996. The 21st Century Organization, Reinventing through Reengineering. Translators: Rachmayanti, Irma Andriani. Jakarta: LPPM.

[5] Bentler, P.M. (1980). Multivariate Analysis with Latent Variabeles: Causal Model, Annual Review of Psychology, 31, 419-456

[6] Bungin, HM Burhan. 2005. Qualitative Research Methods: Communication, Economics, Public Policy and the Social Sciences. Jakarta: Kencana. 


\section{International Journal of Science and Research (IJSR) \\ ISSN (Online): 2319-7064}

Index Copernicus Value (2013): 6.14 | Impact Factor (2014): 5.611

[7] Bryman, Alan. 2004. Social Research Methods 2nded. Oxford: University Press.

[8] Creswell, W. John. 1994. Research Design: Qualitative and Quantitative Approaches. California: Sage Publications, Inc.

[9] Djohanputro, Bramantyo. 2004. The Value-Based Corporate Restructuring: Towards a Strategic Competitive Advantage. Jakarta: PPM.

[10] Dumairy, 1997 "Indonesia's economy", Erland.

[11] Gibson, Ivancevich, Donnelly., 1992. Organization and Management: Behavior, Structure, Processes. Jakarta: Erland.

[12] Guilford, J.P. 1979. Psychometric Methods. New Delhi: Tata McGraw-Hill Publishing Company Limited.

[13] Hammer, Michael \& Chmppy, James. 1995. ReEngineering Company (Reengineering The Corporation). Translators: Widodo, Marcus, Prihmito. Jakarta: Gramedia.

[14] Handoko, Hani, et al. 2004. Organizational Strategy. Yogyakarta: Amara Books.

[15] Hasibuan, Malay S.P. 1999. Organization and Motivation: Primary Productivity Improvement. Jakarta: Earth Literacy.

[16] Jones, Gareth R. 2007. Organizational Theory, Design and Change. Pearson Prentice Hall, New Jersey.

[17] Kotler, Philip. and Kevin Lane Keller. 2012. Marketing Management, thirteenrd Edition. Pearson.

[18] Kurniawan Dedy. 2012. Influence of Organizational Restructuring of the Service Quality Land Certificate in the Land Office Depok. Thesis Public Administration Padjadjaran Bandung.

[19] Report of the Central Statistics Agency (BPS), Various Years

[20] Report of the World Bank, Various Year

[21] Liliweri, Alo. 1997. Sociology of Organizations. Bandung: Aditya Citra Bhakti.

[22] Lovelock, Christopher H. 2001. Principleof Service Marketing and Management. Second Edition. Prentice Hall

[23] Mankiw, N. Gregory, 2000, "Macroeconomic Theory", 4th Edition, Jakarta, erlangga

[24] Mc Gill, GA. 1993. Introduction on Management Study. New York: McMillian.

[25] Miles, Jeffrey A. 2012. Management and Organization Theory, John Willey and Sons, San Francisco.

[26] Mintzberg, H. 1979. Organizational Power and Goals in Charless Hofer and Dan Schedel., Strategic Management: A New View of Businesss Policy and Planning. Boston: Little Brown.

[27] Effective Organization. Englewood Cliffs, NJ: Prentice Hall.

[28] Nasution, M. A., S. 1964. Principles Curriculum, Bandung. Publisher Terate.

[29] Robbins, Stephen P. 1994. Organization Theory: Structure, Design and Applications. Udaya Jusuf translation, Organization Theory: structure, design and application. Arcan.

[30]

1996. Organizational Behavior:

Concepts, Controversies and Applications. Pujaatmaka Hadyana interpreter. Jakarta: Prenhallindo.

[31]__. And Mary Coulter. 1999. Management. Translation by $\mathrm{T}$. Hermaya. Jakarta: Prenhallindo.

[32] Sedarmayanti. 2000. Restructuring and Empowerment Organization in Dealing Dynamics Environmental Change. Bandung: Mandar Maju.
[33] Siagian, Sondra P. 2004. Human Resource Management. Jakarta: Earth Literacy.

[34] Jakarta: Earth Literacy.

2003. Strategic Management

[35] Steers, Richard M. 1985. Organizational Effectiveness Magdalena translation Jamin. Jakarta: Erland.

[36] Sudjana. 1992. Methods of Statistics. Jakarta: BPFE.

[37] Susilowati, Rahayu. 2003. Restructuring Organization Regional Office In Creating Quality Public Services (Studies in Social Service and Empowerment of Women Bandar Lampung). Thesis Social Science Padjadjaran Bandung.

[38] Todaro, Michael P, 2000, the "Economic Development", 7th edition, Pearson Education Limited

[39] Winardi. 2003. Theory of Organization and Organizing. Jakarta: RajaGrafindo

[40] Zeithaml, Valerie A and Mary Bitner, 1996. Service Marketing. Mc Graw-Hill Education (India). Pvt Limited

[41] Zulfakri. 2002. Influence of Organizational Restructuring Social Welfare Department of the Public Service Quality Palembang. Thesis Social Sciences Padjadjaran Bandung.

[42] Bandung Regional Regulation No. 62001 on the establishment of technical and organizational structure of the institution of Bandung City area.

[43] Bandung Regional Regulation No. 12 Year 2007 on the establishment of technical and organizational structure of the institution of Bandung City area.

[44] Bandung Regional Regulation No. 08 Year 2008 on Regional Long Term Development Plan (RPJPD) Year 2005-2025

[45] Bandung Regional Regulation No. 09 Year 2009 on Regional Medium Term Development Plan (Plan) Year 2009-2013.

[46] Bandung Regional Regulation No. 12 Year 2009 on the Amendment Bandung Regional Regulation No. 12 of 2007 on the establishment of technical and organizational structure of the institution of Bandung City area.

[47] Indonesian Government Regulation No. 8 of 2008 on Stages, Procedures for the Preparation, Control, and Evaluation of the Implementation Plan for Regional Development.

[48] Bandung Bappeda Strategic Plan 2009-2013.

[49] Joint Circular of the State Minister of National Development Planning / Head of Bappenas and Minister of the Interior No. 008 / M.PPN / 01/2007/05 / 264A / SJ on Musrenbang 2007.

[50] Law of the Republic of Indonesia No. 25 of 2004 on National Development Planning System.

[51] http://bappeda-bandung.go.id

[52] http://bappeda.jabarprov.go.id

[53] http://www.bandung.go.id

\section{Author Profile}

Dewi Gartika, Researchers in Bandung Municipality Regional Development Planning Agency (Bappeda), 